\title{
Apoptosis and Fas/Fas ligand mRNA expression in acute immune complex alveolitis in mice
}

\author{
Y. Nomoto, K. Kuwano, N. Hagimoto, R. Kunitake, M. Kawasaki, N. Hara
}

Apoptosis and Fas/Fas ligand mRNA expression in acute immune complex alveolitis in mice. Y. Nomoto, K. Kuwano, N. Hagimoto, R. Kunitake, M. Kawasaki, N. Hara. (CERS Journals Ltd 1997.

ABSTRACT: Deoxyribonucleic acid (DNA) strand breaks as a characteristic of apoptosis, and Fas antigen (Fas)/Fas ligand (FasL) expression may participate in acute immune complex alveolitis in mice.

Male Institute for Cancer Research (ICR) mice were injected intravenously with immunoglobulin G (IgG) antibodies against ovalbumin and inhaled an aerosolized oval albumin (OA) solution. They were killed at 4, 6, 12, 24, $48 \mathrm{~h}$ and 7 days after aerosolization. We assessed DNA fragmentation by agarose gel electrophoresis and terminal deoxynucleotidyl transferase-mediated deoxyuridine triphosphate biotin nick end-labelling (TUNEL). The expression of Fas and FasL messenger ribonucleic acid (mRNA) in lung tissues was assessed by reverse transcriptase (RT) polymerase chain reaction, and by in situ hybridization (ISH) to localize Fas mRNA, and RT in situ polymerase chain reaction to localize FasL mRNA.

The fragmentation of DNA extracted from lung tissue was found 6-24 h after OA inhalation. TUNEL detected positive signals in bronchial and alveolar epithelial, endothelial and inflammatory cells in the lung tissue. These positive signals had disappeared 7 days after OA inhalation. TUNEL also detected positive signals in apoptotic neutrophils in bronchoalveolar lavage fluid at 6-12 h. Fas mRNA was expressed in the alveolar epithelial and inflammatory cells, while the expression of FasL mRNA appeared to be upregulated in infiltrating inflammatory cells at 6-24 h.

These results suggest that apoptosis may be associated with the resolution of inflammation and with tissue repair and also suggest the involvement of the Fas antigen/Fas ligand pathway in acute immune complex alveolitis in mice.

Eur Respir J 1997; 10: 2351-2359.
Research Institute for Diseases of the Chest, Faculty of Medicine, Kyushu University, Fukuoka 812, Japan.

\section{Correspondence: K. Kuwano}

Research Institute for Diseases of the Chest Faculty of Medicine

Kyushu University

3-1-1, Maidashi

Higashiku

Fukuoka 812

Japan

Keywords: Acute lung injury

apoptosis

Fas antigen

Fas ligand

Received: November 251996

Accepted after revision June 191997
Acute inflammation has evolved as part of the beneficial host response to injury and infection, that normally resolves with minimal residual tissue damage [1, 2]. Postinflammatory scarring or fibrosis is a cause of disease in acute lung injury, where it accounts for most cases of respiratory failure. Therefore, the resolution of inflammation and tissue repair without fibrosis is particularly important for successful tissue remodelling. The apoptosis of unwanted cells in the remodelling process is an important mechanism for the repair of injured lung tissue without prolonging the period of inflammation [3]. It is now increasingly recognized that unwanted cells are cleared by apoptosis, which eliminates cells without inciting an inflammatory response. Dying cells undergoing apoptosis are recognized quickly and ingested by phagocytes before they release their toxic contents. This is in contrast to the processes involved in accidental cell death or necrosis $[4,5]$.

Fas is a cell-surface protein that mediates apoptosis. It is expressed in various cells and tissues including the thymus, liver, ovary, heart and lung. It has structural homology with a number of cell surface receptors, including tumour necrosis factor (TNF) receptor and nerve growth factor receptor [6]. The Fas ligand (FasL), a cell surface molecule belonging to the TNF family, binds to its receptor Fas, thus inducing the apoptosis of Fas-bearing cells [7]. In contrast to the tissue distribution of Fas, constitutive expression of FasL is relatively limited [7]. In the immune system, Fas and FasL are involved in the down-regulation of immune reactions [8-10]. Recently, LiLES et al. [11] demonstrated that mature neutrophils constitutively expressed cell-surface Fas and FasL, and suggested that constitutive expression of Fas/FasL may be a plausible mechanism for the rapid rate of spontaneous apoptosis observed in mature human neutrophils. TSUYUKI et al. [12] demonstrated that murine lung eosinophils express Fas and can undergo apoptosis following receptor activation. Furthermore, Fas activation in vivo leads to the recognition of eosinophils by lung macrophages, resulting in resolution of eosinophilic inflammation.

Although there are a number of previous reports examining inflammatory cell or resident cell apoptosis in diverse situations $[13,14]$, there is still uncertainty as regards inflammatory and resident cell apoptosis, and deoxyribonucleic acid (DNA) strand breaks in acute 
lung injury in vivo. Although Fas and FasL messenger ribonucleic acid (mRNA) are known to be expressed in rat lung $[6,7]$, their expressions in the pathological state of the lung have not been examined. Therefore, we investigated DNA strand breaks as a characteristic of apoptosis and the expressions of Fas/FasL mRNA in acute lung injury. We used a mouse model of acute immune complex alveolitis, where a prompt, marked neutrophilic response in the lung causes acute alveolitis, and the inflammation resolves completely without evidence of intra-alveolar granulation or fibrosis [15].

\section{Materials and Methods}

\section{Animals and study design}

The materials and methods were described previously [15]. Briefly, New Zealand White rabbits weighing 2.0$2.5 \mathrm{~kg}$ were immunized repeatedly with $1 \mathrm{mg}$ of ovalbumin (OA) in complete Freund's adjuvant. Antibodies against $\mathrm{OA}$ were affinity-purified from the antisera using an OA-coupled sepharose column. The immunoglobulin $\mathrm{G}$ (IgG) antibodies were purified by diethylaminoethyl (DEAE)-cellulose as described previously [16]. Half a milligram of the purified anti-OA IgG antibody in $1 \mathrm{~mL}$ of phosphate-buffered saline (PBS) was injected intravenously into 6 week old Institute for Cancer Research (ICR) mice weighing $30 \mathrm{~g}, 1 \mathrm{~h}$ prior to $\mathrm{OA}$ inhalation. Groups of mice $(n=50)$ were put in a chamber and challenged with $15 \mathrm{~mL}$ of aerosolized OA solution $\left(5 \mathrm{mg} \cdot \mathrm{mL}^{-1}\right.$ in PBS). This took approximately 60 min to complete. The mice then were left in the chamber for an additional 15 min before being transferred to room air. The control mice $(n=18)$ were challenged with injection of nonimmune rabbit IgG with OA inhalation $(n=6)$, with OA inhalation alone $(n=6)$, or with saline inhalation $(n=6)$. The animals $(n=7$ at each time point) were anaesthetized with ether at 4, 6, 12, 24, 48 $\mathrm{h}$ and 7 days after OA inhalation. After thoracotomy, samples of right lung were fixed in $10 \%$ formalin for $24 \mathrm{~h}$ and processed separately for light microscopy and terminal deoxynucleotide transferase-mediated deoxyuridine triphosphate (dUTP) biotin nick end-labelling (TUNEL). Half of the left lung was immediately frozen in liquid nitrogen for ribonucleic acid (RNA) and DNA extraction. The other half was fixed with $4 \%$ paraformaldehyde for $4 \mathrm{~h}$ at $4^{\circ} \mathrm{C}$, and infused in $0.5 \mathrm{M}$ sucrose solution at $4^{\circ} \mathrm{C}$ overnight for in situ hybridization (ISH) and reverse transcriptase (RT) in situ polymerase chain reaction $(\mathrm{PCR})$.

\section{Bronchoalveolar lavage}

The animals ( $\mathrm{n}=4$ at each time point) were anaesthetized with ether at $6,12,24,48 \mathrm{~h}$ and 7 days after OA inhalation. After thoracotomy, bronchoalveolar lavage (BAL) was performed through an inserted tracheal tube using a total of $5 \mathrm{~mL}$ of sterile physiological saline solution. The cells in the lavage fluid were counted using a haemocytometer. Differential counts were performed on a total of 100 cells stained with Wright and Giemsa stain.
Analysis of DNA fragmentation on agarose gel electrophoresis

The lungs were minced using a razor blade and suspended in $500 \mathrm{ng} \cdot \mathrm{mL}^{-1}$ of proteinase $\mathrm{K}$ solution (AMRESCO Inc., Solon, $\mathrm{OH}, \mathrm{USA}$ ). The samples were incubated at $50^{\circ} \mathrm{C}$ overnight and then extracted with a phenol/ $\mathrm{CHCl}_{3}$ mixture (1:1). After ethanol precipitation, $10 \mu \mathrm{g}$ of each DNA was electrophoresed on a $1 \%$ agarose gel and visualized after staining with ethidium bromide.

In situ DNA nick end-labelling of cell and tissue sections

The TUNEL method was performed according to the protocols described by GAVRIELI et al. [17] with slight modifications [18].

\section{RNA preparation and RT-PCR analysis}

Total RNA was prepared from lung tissues by the Isogen RNA extraction kit (Nippon Gene, Tokyo, Japan) according to the manufacturer's recommendations. After RNA was treated with deoxyribonuclease (DNAse) I (GIBCO BRL, Gaithersburg, MD, USA), complementary DNA (cDNA) was prepared by reverse transcription of $4 \mu \mathrm{g}$ of each RNA sample in a $20 \mu \mathrm{L}$ reaction volume containing $10 \mathrm{mM}$ Tris $\mathrm{HCl}$ (pH 8.8) (WAKO, Osaka, Japan), $50 \mathrm{mM} \mathrm{KCl}$ (WAKO), $4 \mathrm{mM} \mathrm{MgCl}_{2}$ (WAKO), $0.1 \%$ Triton X-100 (Sigma, St Louis, MO, USA), $1 \mathrm{mM}$ dithiothreitol (DTT) (AMRESCO), $0.25 \mathrm{mM}$ deoxynucleotide triphosphate (dNTP), $5 \mu \mathrm{M}$ random hexamer primers, $0.1 \mathrm{U} \cdot \mu \mathrm{L}^{-1}$ ribonuclease inhibitor (Promega Corp., Madison, WI, USA) and $10 \mathrm{U} \cdot \mu \mathrm{L}^{-1}$ of Molonymurine leukaemia virus reverse transcriptase (MMLV$\mathrm{RT}$ ) (GIBCO BRL). The reaction mixture was incubated at $42^{\circ} \mathrm{C}$ for $1 \mathrm{~h}$, and at $95^{\circ} \mathrm{C}$ for $5 \mathrm{~min}$. The cDNAs were then diluted to $100 \mu \mathrm{L}$, and the same DNA mixtures were used in all PCRs. PCR amplifications were performed in a $50 \mu \mathrm{L}$ reaction volume containing $5 \mu \mathrm{L}$ of each cDNA, $10 \mathrm{mM}$ Tris $\mathrm{HCl}(\mathrm{pH} 8.8), 50 \mathrm{mM}$ $\mathrm{KCl}, 1.5 \mathrm{mM} \mathrm{MgCl}$ for Fas and FasL PCR or $2.5 \mathrm{mM}$ $\mathrm{MgCl}_{2}$ for $\beta$-actin PCR, $0.2 \mathrm{mM}$ dNTPs, and $1.25 \mathrm{U}$ of Taq polymerase (Takara Biochemicals, Otsu, Japan). The primers and probes used were as follows:

1) $\beta$-actin:

sense 5'-TCCTGTGGCATCCATGAAACT-3' antisense 5'-CTTCGTGAACGCCACGTGCTA-3' probe 5'-GGAGATTACTGCTCTGGCTC-3'

2) Fas:

sense 5'-TTGCTGTCAACCATGCCAAC-3' antisense 5'-ACGTGAACCATAAGACCCAG-3' probe 5'-TGCACAGAAGGGAAGGAGTACATGGACAAG-3' 3) FasL:

sense 5'-ATCCCTCTGGAATGGGAAGA-3' antisense 5'-CCATATCTGTCCAGTAGTGC-3' probe 5'-GAGGATCTGGTGCTAATGGA-3' 4) pUC19:

sense 5'-CATTTTGCCTTCCTGTTTTT-3' antisense 5'-GCTTTTCTGTGTGACTGGTG-3' 
The conditions for amplification were as follows: $\beta$ actin and FasL; pUC19, $93^{\circ} \mathrm{C}$ for 3 min for 1 cycle, then $93^{\circ} \mathrm{C}$ for $1 \mathrm{~min}, 55^{\circ} \mathrm{C}$ for $1 \mathrm{~min}$, and $72^{\circ} \mathrm{C}$ for 2 min for 35 cycles, and $72^{\circ} \mathrm{C}$ for 7 min for 1 cycle; Fas, $93^{\circ} \mathrm{C}$ for $3 \mathrm{~min}$ for $1 \mathrm{cycle}, 93^{\circ} \mathrm{C}$ for $1 \mathrm{~min}, 63^{\circ} \mathrm{C}$ for $1 \mathrm{~min}$, and $72^{\circ} \mathrm{C}$ for $2 \mathrm{~min}$ for 35 cycles, and $72^{\circ} \mathrm{C}$ for 7 min for 1 cycle. The number of cycles was the same for each pair of primers. Cycle curve studies confirmed that the reactions had not reached the plateau of the amplification curve for any primer pair. Negative controls performed with no RT yielded no detectable fragments with either primer pair. Fas, FasL and $\beta$-actin PCR products were transferred to filter and hybridized with an oligonucleotide probe labelled with digoxigenin-dideoxyuridine triphosphate (ddUTP) (Boehringer Mannheim, Mannheim, Germany) using the DIG Oligonucleotide 3'-End Labelling Kit (Boehringer Mannheim). Digoxigenin-labelled probes that hybridized with the PCR products were detected with the DIG Nucleic Acid Detection Kit (Boehringer Mannheim).

\section{Double-stranded PCR probe labelling with digoxigenin}

Digoxigenin-labelled PCR probes for Fas mRNA and for pUC19, as a double-stranded DNA control probe, were synthesized in $25 \mu \mathrm{L}$ reaction volumes containing $70 \mu \mathrm{M}$ digoxigenin 11-dUTP, $10 \mathrm{mM}$ Tris $\mathrm{HCl}(\mathrm{pH}$ $8.8), 50 \mathrm{mM} \mathrm{KCl}, 2.5 \mathrm{mM} \mathrm{MgCl}, 0.2 \mathrm{mM}$ each of unlabelled deoxyadenosine triphosphate (dATP), deoxycytosine triphosphate (dCTP), deoxyguanine triphosphate (dGTP), $0.13 \mathrm{mM}$ unlabelled deoxythymidine triphosphate (dTTP), primer pairs specific for Fas cDNA or for pUC19 DNA, $40 \mathrm{ng}$ of PCR product of Fas cDNA or pUC19 DNA, and $1.25 \mathrm{U}$ of Taq polymerase. After ethanol precipitation, the pellet was resuspended in two parts hybridization mix, containing $1.2 \mathrm{M} \mathrm{NaCl}, 20$ $\mathrm{mM}$ Tris $\mathrm{HCl}(\mathrm{pH} 7.5), 4 \mathrm{mM}$ ethylenediamine tetraacetic acid (EDTA), $2 \times$ Denhardt's solution, $1 \mathrm{mg} \cdot \mathrm{mL}^{-1}$ yeast transfer RNA (tRNA), and $200 \mu \mathrm{g} \cdot \mathrm{mL}^{-1}$ poly(A) (Pharmacia Diagnostics AB, Uppsala, Sweden), two parts deionized formamide, and one part $50 \%$ dextran sulphate. To verify that the incorporation of digoxigenin of each of the probes was similar, $1 \mu \mathrm{L}$ each of probe was fixed to Hybond-N hybridization membrane (Amersham Corp., Arlington Heights, IL, USA), and detected with an anti-digoxigenin antibody using the DIG Nucleic Acid Detection Kit. The intensities of the signals of Fas, and pUC19 probes were equivalent to each other.

\section{In situ hybridization (ISH) for Fas mRNA}

Two $6 \mu \mathrm{M}$ cryosections were placed on poly-L lysin coated slides. The cryosections were covered with $4 \%$ paraformaldehyde (PFA) for $5 \mathrm{~min}$ at room temperature. After dehydration with ethanol, the section was immersed in $20 \mu \mathrm{g} \cdot \mathrm{mL}^{-1}$ of proteinase $\mathrm{K}$ for $10 \mathrm{~min}$ at $37^{\circ} \mathrm{C}$, rinsed in PBS containing $2 \mathrm{mg} \cdot \mathrm{mL}^{-1}$ glycine for $30 \mathrm{~s}$ and in PBS for $30 \mathrm{~s}$. The slide was immersed in freshly prepared 0.1 M triethanolamine (TEA) (E. Merk, Darmstadt, Germany) solution (TEA buffer) for $5 \mathrm{~min}$, and in TEA buffer containing $0.25 \%$ acetic anhydride (Sigma) for $10 \mathrm{~min}$. The PCR probe hybridization mixture was incubated for 5 min at $93^{\circ} \mathrm{C}$, chilled in an ice bath, and DTT was added to yield a final concentration of $50 \mathrm{mM}$. One section from each slide was incubated with $5 \mu \mathrm{L}$ of hybridization solution with Fas probe, and the other section on the same slide was incubated with pUC19 probe solution. The slide was incubated at $37^{\circ} \mathrm{C}$ overnight in a well-sealed chamber containing moist chamber solution $(50 \%$ formamide (WAKO), $0.6 \mathrm{M} \mathrm{NaCl}$, $10 \mathrm{mM}$ Tris $\mathrm{HCl}$ (pH 7.5), and 2 mM EDTA (WAKO)). After hybridization, the slide was washed four times with a solution containing $0.6 \mathrm{M} \mathrm{NaCl}, 10 \mathrm{mM}$ Tris $\mathrm{HCl}$ (pH 7.5), 1 mM EDTA, 50\% formamide, and $0.1 \%$ $\beta$-mercaptoethanol (AMRESCO) for $10 \mathrm{~min}$ each at $37^{\circ} \mathrm{C}$. The slide was washed twice at room temperature with buffer $1(0.1 \mathrm{M}$ Tris $\mathrm{HCl}(\mathrm{pH} 7.6), 0.1 \mathrm{M}$ $\mathrm{NaCl}, 2 \mathrm{mM} \mathrm{MgCl}$, and $0.05 \%$ Triton X-100) for 5 min, incubated with $3 \%$ bovine serum albumin (BSA) (Sigma) in buffer 1 for $10 \mathrm{~min}$, and finally incubated with anti-digoxigenin antibody-alkaline phosphatase conjugate (Boehringer Mannheim) in 3\% BSA in buffer 1 for $30 \mathrm{~min}$. The slide was washed with buffer 1 , immersed in alkaline phosphatase reaction buffer (AP) ( $\mathrm{pH}$ 9.6) solution containing 0.1 M Tris $\mathrm{HCl}(\mathrm{pH} 9.6)$, $0.1 \mathrm{M} \mathrm{NaCl}$, and $0.05 \mathrm{M} \mathrm{MgCl}_{2}$, and incubated in nitroblue tetrazolium (NBT)/5-bromo-4-chloro-3-indolylphosphate disodium salt (BCIP) colour reaction solution in AP 9.6 for 10 min in the dark.

\section{$R T$ in situ PCR for FasL $m R N A$}

RT in situ PCR was performed as described previously [19]. Briefly, poly-L lysin coated slides containing cryosections were fixed in $10 \%$ buffered formalin for $8 \mathrm{~h}$. After digestion with $20 \mu \mathrm{g} \cdot \mathrm{mL}^{-1}$ proteinase $\mathrm{K}$ for $10 \mathrm{~min}$ at $37^{\circ} \mathrm{C}$, sections were treated with ribonuclease (RNase)-free DNase I at $37^{\circ} \mathrm{C}$ overnight. The specimens were incubated on the glass slide at $42^{\circ} \mathrm{C}$ for 30 min with $10 \mu \mathrm{L}$ of a solution which contained the downstream primer $(1 \mu \mathrm{M})$ and MMLV-RT. The solution for the amplification of the FasL cDNA contained $4.5 \mathrm{mM} \mathrm{MgCl} 2,200 \mu \mathrm{M}$ each of dATP, dCTP, dGTP and dTTP, $10 \mu \mathrm{M}$ of digoxigenin-dUTP (Boehringer Mannheim), $1 \mu \mathrm{M}$ of each primer, $100 \mu \mathrm{g} \cdot \mathrm{mL}^{-1}$ of BSA, and 5 units of Taq polymerase in $25 \mu \mathrm{L}$ amplifying solution. The conditions for amplification were $93^{\circ} \mathrm{C}$ for $1 \mathrm{~min}, 55^{\circ} \mathrm{C}$ for $2 \mathrm{~min}$, for 20 cycles. The digoxigenindUTP labelled PCR product was detected after incubation with an alkaline phosphatase anti-digoxigenin conjugate $(1: 500$ dilution in $0.1 \mathrm{M}$ Tris- $\mathrm{HCl}, \mathrm{pH} 7.6$, $0.1 \mathrm{M} \mathrm{NaCl}, 2 \mathrm{mM} \mathrm{MgCl} 2,0.05 \%$ Triton X-100, and $3 \% \mathrm{BSA}$ ) for $30 \mathrm{~min}$ and development in NBT/BCIP colour reaction solution for $30 \mathrm{~min}$ in a dark room. The positive control for RT in situ PCR was to eliminate DNase digestion. An intense nuclear signal was generated from target-specific amplification, DNA repair and mispriming [19]. This control demonstrated that the PCR reaction and the subsequent detection steps worked. The negative control was RT in situ PCR in which the tissue was treated with DNase I and the reverse transcription step was eliminated. The absence of a signal demonstrated that amplification of genomic DNA was not occurring. 


\section{Results}

\section{Kinetics of changes in the BAL cell number}

Table 1 shows the results of the BAL cell number analysis. OA inhalation induced a prompt influx of leucocytes that was evident at $6 \mathrm{~h}$. After $12 \mathrm{~h}$, there was a rapid clearing of cells from the lower respiratory tract as indicated by the large decrease in the neutrophil population. Eosinophils were rarely found in BAL fluid.

\section{Neutrophil apoptosis in BAL fluid}

At $6 \mathrm{~h}$ after OA inhalation, when the neutrophil influx was established, TUNEL staining detected DNA strand breaks in many neutrophils. The intensity of TUNEL staining in nuclei was light and diffuse (fig. 1a). At $12 \mathrm{~h}$ after $\mathrm{OA}$ inhalation, there were typical apoptotic neutrophils, in which the TUNEL staining pattern was small and condensed, and macrophages had engulfed the apoptotic neutrophils or apoptotic bodies (figs. 1b and 1c). Apoptotic neutrophils were found in diminishing numbers, paralleling the decline in total neutrophils present. We counted the number of macrophages engulf- ing apoptotic neutrophils or apoptotic bodies in BAL fluid. The number of these macrophages were $1,6,31$, 16 , and $6 \%$ at $6,12,24,48 \mathrm{~h}$ and 1 week, respectively.

DNA fragmentation analysis in lung tissue by the TUNEL technique

Figure 2A shows thickening of the alveolar septa, with infiltration of neutrophils and mononuclear cells accompanied by intra-alveolar haemorrhage at $6 \mathrm{~h}$ after OA inhalation. TUNEL demonstrated positive signals in bronchiolar and alveolar epithelial cells, endothelial cells, and inflammatory cells (figs. 2B, C and D) at 6 h. The areas stained by TUNEL were diffused at 6-48 h. At 7 days after OA inhalation, inflammatory cells (fig. 2E) and positive signals by TUNEL had almost disappeared (fig. 2F). Positive signals by TUNEL were not detected in lung tissues from control mice.

\section{DNA fragmentation on agarose gel electrophoresis}

The DNA fragmentation was detected from 6-48 $\mathrm{h}$ after OA inhalation, and was most intense at $12 \mathrm{~h}$. DNA

Table 1. - Intra-alveolar cell number in bronchoalveolar lavage fluid

\begin{tabular}{lccccc}
\hline & $\begin{array}{c}\text { Samples } \\
\mathrm{n}\end{array}$ & $\begin{array}{c}\text { Total cells } \\
\times 10^{5} \text { cells } \cdot \mathrm{mL}^{-1}\end{array}$ & $\begin{array}{c}\text { Macrophages } \\
\times 10^{5} \text { cells } \cdot \mathrm{mL}^{-1}\end{array}$ & $\begin{array}{c}\text { Neutrophils } \\
\times 10^{5} \text { cells } \cdot \mathrm{mL}^{-1}\end{array}$ & $\begin{array}{c}\text { Lymphocytes } \\
\times 10^{5} \text { cells } \cdot \mathrm{mL}^{-1}\end{array}$ \\
\hline Control & 4 & $0.23 \pm 0.11$ & $0.20 \pm 0.10$ & $0.01 \pm 0.01$ & $0.01 \pm 0.01$ \\
OA treated & & & & & \\
$6 \mathrm{~h}$ & 2 & $103.5 \pm 23.33$ & $10.9 \pm 13.16$ & $85.6 \pm 7.89$ & $0.98 \pm 0.88$ \\
$12 \mathrm{~h}$ & 3 & $16.8 \pm 6.32$ & $3.9 \pm 2.68$ & $12.8 \pm 3.71$ & $0.14 \pm 0.09$ \\
$24 \mathrm{~h}$ & 4 & $9.8 \pm 1.29$ & $2.2 \pm 0.35$ & $7.4 \pm 1.61$ & $0.25 \pm 0.02$ \\
$48 \mathrm{~h}$ & 4 & $2.7 \pm 2.26$ & $0.69 \pm 0.43$ & $2.0 \pm 1.81$ & $0.03 \pm 0.02$ \\
1 week & 4 & $0.15 \pm 0.06$ & $0.13 \pm 0.06$ & $0.01 \pm 0.01$ & $0.01 \pm 0.01$ \\
\hline
\end{tabular}

Data are presented as mean \pm SEM. Control: untreated mice; OA treated: mice subjected to ovalbumin (OA) inhalation.

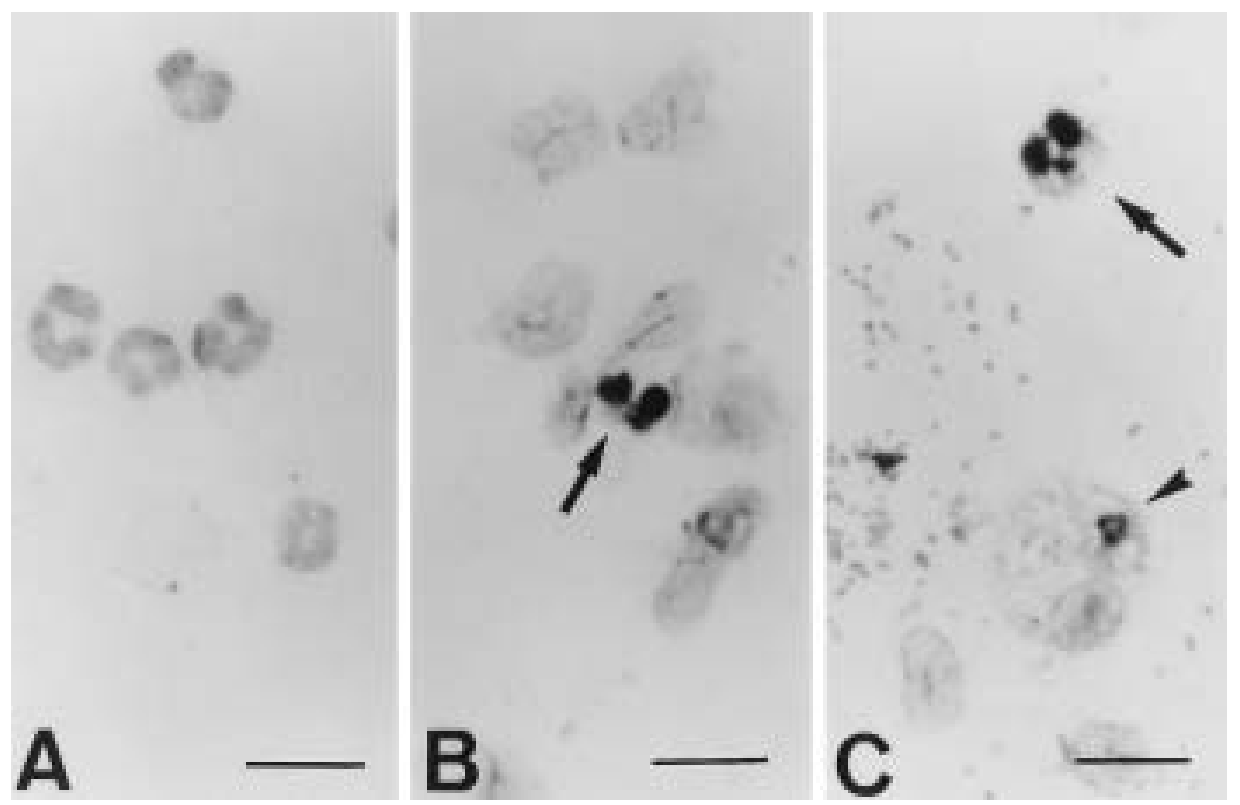

Fig. 1. - Apoptotic neutrophils detected by terminal deoxynucleotidyl/transferase-mediated deoxyuridine triphosphate biotin nick end-labelling (TUNEL): A) at $6 \mathrm{~h}$ after ovalbumin (OA) inhalation, many neutrophils were stained lightly, but the nuclei of these cells did not appear apoptotic; B) at $12 \mathrm{~h}$ after OA inhalation, the positively stained neutrophils appeared apoptotic (arrow); and C) were engulfed by macrophages (arrowhead). Internal scale bars $=40 \mu \mathrm{m}$. 

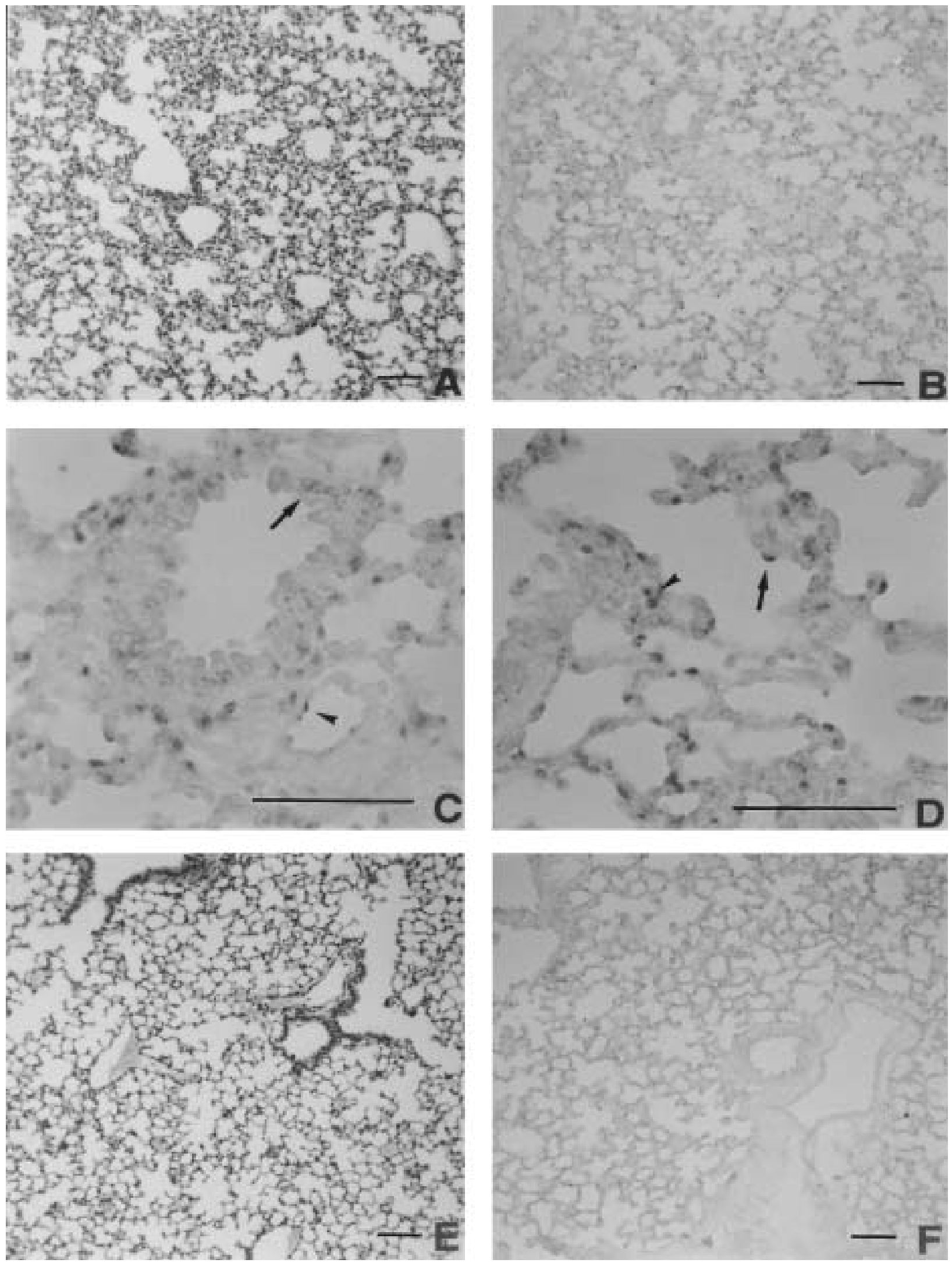

Fig. 2. - Deoxyribonucleic acid (DNA) strand breaks as a characteristic of apoptosis detected by TUNEL in lung tissues: A) at $6 \mathrm{~h}$ after OA inhalation, haematoxylin and eosin staining shows that the alveolar septa were thickened with infiltration of neutrophils and mononuclear cells; B) positive signals by TUNEL were diffusely distributed at $6 \mathrm{~h}$. TUNEL demonstrated: C) bronchiolar epithelial cells (arrow) and endothelial cells (arrowhead; at $6 \mathrm{~h}$; D) DNA strand breaks in alveolar epithelial cells (arrow) and infiltrative inflammatory cells (arrowhead)) at $6 \mathrm{~h}$. At 7 days after OA inhalation there was almost complete resolution of: E) the inflammation in the lung; and F) positive signals by TUNEL. Internal scale bars $=150 \mu \mathrm{m}$. For definitions see legend to figure 1 . 
a)
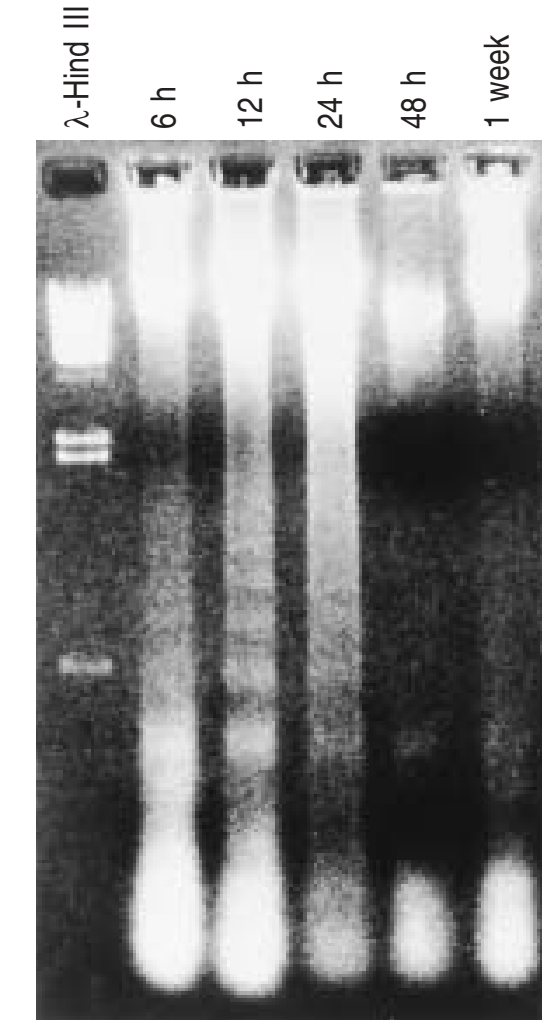

b)

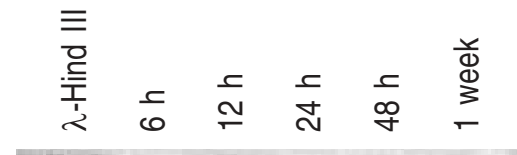

$\mathrm{h}$ after OA inhalation, whereas it was very weakly expressed in lung tissues of control mice.

\section{Results of ISH for Fas mRNA}

Expression of Fas mRNA was detected in alveolar epithelial cells and inflammatory cells using the Fas PCR probe, but not with a pUC19 PCR probe at any time point after OA inhalation (fig. 5). Fas mRNA expression was also detected in alveolar epithelial cells in the control lung.

Results of $R T$ in situ PCR for FasL mRNA

Expression of FasL mRNA was detected in putative inflammatory cells infiltrating lung tissues at $12 \mathrm{~h}$ after OA inhalation (fig. 6A), while FasL mRNA was not detected in control lung tissues (fig. 6B) or at 7 days after OA inhalation. A positive control, in which the DNase step was not performed, time points after OA inhalation in mice injected with: a) anti OA-immunoglobulin G ( $\operatorname{IgG}$ ) antibody; and b) unrelated IgG antibody. The $10 \mu \mathrm{g}$ of DNA in each lane was electrophoresed on a $1.2 \%$ agarose gel in the presence of $1 \mu \mathrm{g} \cdot \mathrm{mL}^{-1}$ ethidium bromide. For definitions see legend to figure 1.

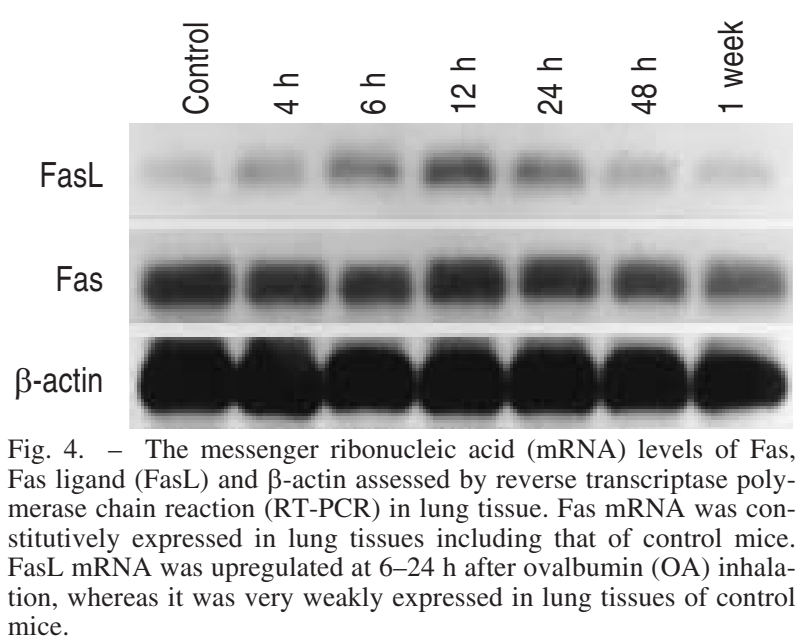

fragmentation had almost resolved after 7 days (fig. 3a). DNA fragmentation was not found in mice injected with nonimmune IgG (fig. 3b).

\section{RT-PCR analysis}

As shown in figure 4, RT-PCR analysis revealed specific hybridization bands of Fas, FasL, and $\beta$-actin mRNA with molecular sizes of 209, 246, and 315 base pairs (bp), respectively. Fas mRNA was expressed constitutively in the lungs of both the OA inhalation mice and the control mice. FasL mRNA was upregulated at 6-24 displayed intense nuclear signals (fig. 6C). A negative control, in which DNase step was performed, and reverse transcription step was eliminated, did not show any signal (fig. 6D).

\section{Discussion}

We demonstrated the incidence of DNA fragmentation in lung tissues and localized the DNA strand breaks or apoptosis in bronchiolar and alveolar epithelial cells, endothelial cells, and inflammatory cells in acute immune complex alveolitis in mice. We also showed that Fas mRNA was expressed in these cells, and FasL mRNA was upregulated in infiltrative inflammatory cells in lung tissue. Therefore, apoptosis and Fas/FasL system may be associated with acute lung injury and resolution of inflammation in this model.

The removal of neutrophils and their potentially histotoxic contents is one prerequisite for the resolution of alveolitis. The engulfment of neutrophils by macrophages is an important disposal route, that is associated with their recognition by macrophages [13, 20-22]. At 6-12 $\mathrm{h}$ after the OA challenge, an increasing proportion of the neutrophils in BAL fluid underwent the morphological changes characteristic of apoptosis. Since we could not detect FasL mRNA using the ISH technique, we tried to detect it using the RT in situ PCR technique. The results of RT-PCR and RT in situ PCR showed that the expression of FasL mRNA was upregulated at 6-24 $\mathrm{h}$ in putative inflammatory cells after OA inhalation. 

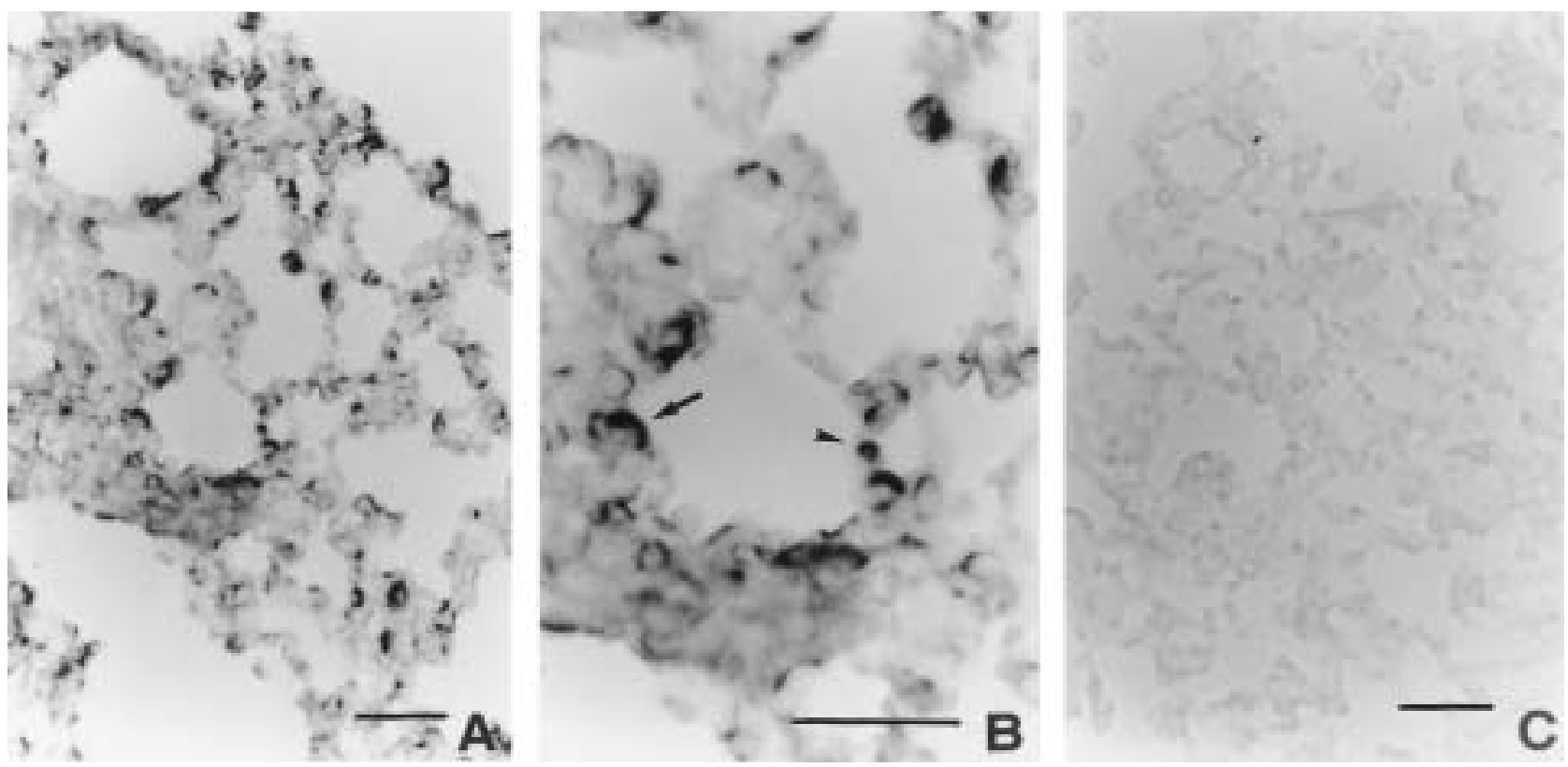

Fig. 5. - Localization of Fas mRNA in lung tissues by in situ hybridization (ISH) at $12 \mathrm{~h}$ after OA inhalation: A, B) Fas mRNA was expressed in alveolar epithelial cells (arrows) and inflammatory cells (arrowheads), which was representative of all time points after OA inhalation; C) there were no positive signals in another section of the same slide hybridized with pUC19 probe. Internal scale bars=100 $\mu \mathrm{m}$. For definitions see legend to figure 4 .
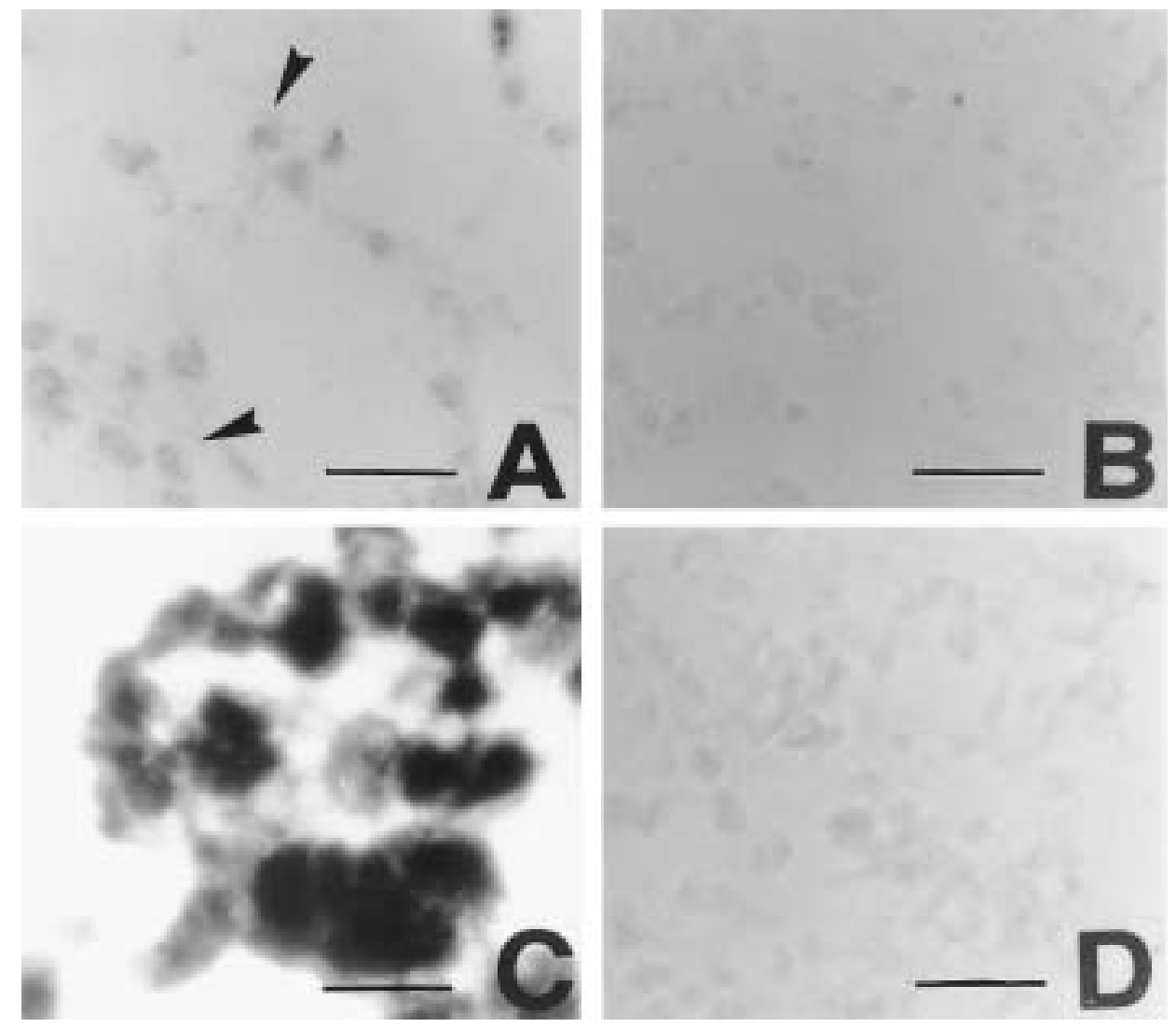

Fig. 6. - Localization of FasL mRNA in lung tissues by reverse transcriptase (RT) in situ polymerase chain reaction (PCR): A) positive signals were detected in putative infiltrating inflammatory cells at $12 \mathrm{~h}$ after OA inhalation (arrowheads); B) no such signals were detected in lung tissues from untreated mice; C) intense nuclear signals were present in the positive control, where if the deoxyribonuclease (DNase) digestion step was omitted. This reflects genomic deoxyribnucleic acid (DNA) amplification, mispriming, and repair; D) no signal was detected in the negative control, which was treated with DNase, and not subjected to reverse transcription. Internal scale bars $=40 \mu \mathrm{m}$. For definitions see legend to figure 4. 
These results suggested that there was an association between apoptosis in neutrophils and expression of FasL mRNA. LiLEs et al. [11] also proposed that Fas/FasL pathway may represent a key mechanism regulating the rapid spontaneous turnover of neutrophils after their release from the marrow. They also demonstrated that only neutrophils were found to undergo rapid apoptosis after stimulation with agonistic anti-Fas antibody, although neutrophils, monocytes, and eosinophils were shown to express cell-surface Fas [11]. These results suggest that apoptosis and Fas/FasL pathway are important mechanisms for the removal of neutrophils during recovery from inflammation, which limit the degree of tissue injury.

The TUNEL method appears to be sensitive enough to detect not only the early stages of the apoptotic process, but also apoptosis of small numbers of cells [17]. GAVRIELI et al. [17] demonstrated that TUNEL positive staining, in the light, was confined to the nuclear periphery. As the labelling intensified, it expanded into the centre of the nucleus. They suggested that DNA fragmentation is probably initiated at the nuclear periphery and progresses toward the centre. We also found a similar staining pattern, with light staining of the positive nuclei of neutrophils at $6 \mathrm{~h}$, which had condensed and fragmented by $12 \mathrm{~h}$ (fig. 1).

In lung tissues, TUNEL also detected positive nuclei in bronchiolar and alveolar epithelial cells, endothelial cells, and inflammatory cells at 6-48 h (fig. 2). DNA fragmentation on agarose gel electrophoresis started to be detected at $6 \mathrm{~h}$ after antigen challenge and became most pronounced at $12 \mathrm{~h}$; thereafter, it gradually disappeared (fig. 3).

Fragmented DNA appears as a series of bands when viewed on agarose gels; this "DNA ladder" has often been considered the biochemical hallmark of apoptosis. However, degradation of DNA into large $\left(10^{3} \mathrm{bp}\right)$ fragments also occurs under certain experimental conditions in necrotic cells [23]. Furthermore, the DNA ladder can be produced in liver cells undergoing ischaemic necrosis without demonstrating the characteristic nuclear morphology of apoptosis [24]. TUNEL can detect not only apoptotic cells, but also necrotic cells [17, $25,26]$. A variety of other biological processes may lead to positive staining for TUNEL, such as the nicking of DNA, thought to occur during cellular differentiation $[25,26]$. Necrosis has been confirmed both by the further degradation of the cellular DNA to a continuum of low molecular weight fragments (rather than to discrete oligonucleosomes), and by the microscopic appearance of the cells. In our study, agarose gel electrophoresis identified oligonucleosomal DNA fragments or "DNA smear".

We tried to detect apoptotic cells, but were unable to detect either typical apoptotic or necrotic cells using light and electron microscopy. It was demonstrated that the characteristic DNA ladder on agarose gel electrophoresis can be found not only in histologically defined apoptotic cells, but also in morphologically intact cells going through the process of programmed cell death [27, 28]. TUNEL can also detect early stages of apoptotic cells which are morphologically intact [17]. Therefore, it may be possible that some of the alveolar epithelial cells, or other resident cells in which DNA was not suc- cessfully repaired, may are removed quickly by apoptosis in the same way as inflammatory cells. The number of apoptotic cells which then demonstrated morphological changes that could be detected by electron microscopy, was too small.

Although apoptosis has been implicated before as a homeostatic mechanism, it may have a role in human diseases in two different ways. Firstly, diseases may be caused by a malfunction of the apoptosis pathway. Repair after an acute lung injury requires the elimination of inflammatory cells from the alveolar airspace and walls. The release of cellular contents from inflammatory or resident cells would clearly be undesirable in the normal resolution process of inflammation, since it would lead to persistent inflammation and tissue injury. Proinflammatory cytokines that initiate and amplify acute inflammatory responses can activate neutrophils and prolong their survival [29]. Although glucocorticoids are potent anti-inflammatory agents, their use in sepsisinduced inflammatory responses, has been disappointing [30]. This failure can be explained by the fact that glucocorticoids suppress both Fas-induced and spontaneous apoptosis of normal neutrophils $[11,31]$. Apoptosis of neutrophils and irreversible damage to resident cells observed in this study are probably a physiological mechanism of recovery from acute lung injury. Secondly, excessive apoptosis may play a role in human disease. Hepatocytes transformed with human hepatitis $\mathrm{C}$ virus [32] can express viral antigens and activate CTLs (cytotoxic T-lymphocytes). These CTLs express FasL, which can then bind to Fas on the hepatocytes, and induce them to undergo apoptosis. This process normally occurs to remove virus-infected cells, but excessive apoptosis may lead to fulminant hepatitis. We previously demonstrated the excessive expression of FasL mRNA in infiltrating lymphocytes and excessive apoptosis of alveolar epithelial cells in bleomycin-induced pulmonary fibrosis in mice [33]. In this study, upregulation of FasL was transient and appeared to participate in the exclusion of irreparably damaged resident and inflammatory cells from physiological processes.

In conclusion, we reported the incidence of deoxyribonucleic acid strand breaks as a characteristic of apoptosis and overexpression of Fas ligand messenger ribonucleic acid in acute immune complex alveolitis in mice. Apoptosis may be induced to limit increases in the number of inflammatory cells in the face of a proliferative stimulus, and to mediate the removal of these cells once such a stimulus has passed. It may also participate in tissue remodelling to remove irreparably damaged resident cells without causing the release of their toxic contents. Fas ligand messenger ribonucleic acid is probably overexpressed in inflammatory cells during this process, which suggests a possible involvement of Fas/Fas ligand pathway in the process.

\section{References}

1. Hurley JV. Termination of acute inflammation. I. Resolution. In: Hurley JV, ed. Acute Inflammation. 2nd Edn. London, Churchill Livingstone, 1983; pp. 109-117.

2. Haslett C, Hanson PM. Resolution of inflammation. In: Clark RAF, Henson PM, eds. The Molecular and Cellular Biology of Wound Repair. New York, Plenum Publishing Corp., 1988; pp. 185-211. 
3. Polnovsky VA, Chen B, Henke C, et al. Role of mesenchymal cell death in lung remodeling after injury. $J$ Clin Invest 1993; 92: 388-397.

4. Wyllie AH, Kerr JFR, Currie AR. Cell death: the significance of apoptosis. Int Rev Cytol 1980; 68: 251-306.

5. Cohen JJ. Programmed cell death in the immune system. Adv Immunol 1991; 50: 55-85.

6. Itoh N, Yonehara S, Ishii A, et al. The polypeptide encoded by the cDNA for human cell surface antigen Fas can mediate apoptosis. Cell 1991; 66: 233-243.

7. Suda T, Takahashi T, Golstein T, Nagata S. Molecular cloning and expression of the Fas ligand, a novel member of the tumor necrosis factor family. Cell 1993; 75 : 1169-1178.

8. Dhein J, Walczak H, Bäumler C, Debatin KM, Krammer $\mathrm{PH}$. Autocrine T-cell suicide mediated by APO-1/(Fas/ CD95). Nature 1995; 373: 438-441.

9. Brunner T, Mogil RJ, LaFace D, et al. Cell-autonomous Fas(CD95)/Fas-ligand interaction mediates activationinduced apoptosis in T-cell hybridomas. Nature 1995; 373: 441-444.

10. Ju ST, Panka DJ, Cui H, et al. Fas(CD95)/FasL interactions required for programmed cell death after T-cell activation. Nature 1995; 373: 444-448.

11. Liles WC, Kiener PA, Ledbetter JA, Aruffo A, Klebanoff SJ. Differential expression of Fas (CD95) and Fas ligand on normal human phagocytes: implications for the regulation of apoptosis in neutrophils. J Exp Med 1996; 184: 429-440.

12. Tsuyuki S, Bertrand C, Erard F, et al. Activation of the Fas receptor on lung eosinophils leads to apoptosis and the resolution of eosinophilic inflammation of the airways. J Clin Invest 1995; 96: 2924-2931.

13. Cox G, Crossley J, Xing Z. Macrophage engulfment of apoptotic neutrophils contributes to the resolution of acute pulmonary inflammation in vivo. Am J Respir Cell Mol Biol 1995; 12: 232-237.

14. Baker AJ, Mooney A, Hughes J, Lombardi D, Johnson RJ, Savill J. Mesangial cell apoptosis: the major mechanism for resolution of glomerular hypercellularity in experimental mesangial proliferative nephritis. J Clin Invest 1994; 94: 2105-2116.

15. Nomoto Y, Miyagawa Y, Shiraishi T, et al. Tyrosinespecific protein kinase participates in the pathogenesis of acute immune complex in mice. Respiration 1994; 61: 19-22.

16. Yagawa K, Onoue K, Aida Y. Structural studies of Fc receptors: binding properties, solubilization and partial characterization of $\mathrm{Fc}$ receptors of macrophages. J Immunol 1979; 122: 366-373.

17. Gavrieli Y, Sherman Y, Ben-Sasson SA. Identification of programmed cell death in situ via specific labeling of nuclear DNA fragmentation. J Cell Biol 1992; 119: 493-501.

18. Kuwano K, Kunitake R, Kawasaki M, et al. P21 Waf1/Cip1/Sdi1 and $\mathrm{p} 53$ expression in association with DNA strand breaks in idiopathic pulmonary fibrosis. Am J Respir Crit Care Med 1996; 154: 477-483.
19. Nuovo GJ. PCR in situ Hybridization: Protocols and Applications. 2nd Edn. New York, Raven Press, 1994.

20. Newman SL, Henson JE, Henson PM. Phagocytosis of senescent neutrophils by human monocytes-derived macrophages and rabbit inflammatory macrophages. $J$ Exp Med 1982; 156: 430-442.

21. Savill JS, Willie AH, Henson JE, Walport ME, Henson PM, Haslett C. Macrophage phagocytosis of aging neutrophils in inflammation. J Clin Invest 1989; 83: 865-875.

22. Savill JS, Hogg H, Ren Y, Haslett C. Thrombospondin cooperates with CD 36 and the vitronectin receptor in macrophage recognition of neutrophils undergoing apoptosis. J Clin Invest 1992; 90: 1513-1522.

23. Bicknell GR, Cohen GM. Cleavage of DNA to large kilobase pair fragments occurs in some forms of necrosis as well as apoptosis. Biochem Biophys Res Commun 1995; 207: 40-47.

24. Fukuda K, Kojiro M, Chiu JF. Demonstration of extensive chromatin cleavage in transplanted morris hepatoma 7777 tissue: apoptosis or necrosis? Am J Pathol 1993; 142: 935-946.

25. Coulton GR, Rogers B, Strutt P, Skynner MJ, Watt DJ. In situ localization of single-stranded DNA breaks in nuclei of a subpopulation of cells within generating skeletal muscle of the dystrophic mdx mouse. J Cell Sci 1992; 102: 653-662.

26. Ansari B, Coates PJ, Greenstein BD, Hall PA. In situ end-labeling detects DNA strand breaks in apoptosis and other physiological and pathological states. J Pathol 1993; 170: 1-8.

27. Umansky SR. The genetic program of cell death. Hypothesis and some applications: transformation, carcinogenesis, and aging. J Theor Biol 1982; 97: 591-602.

28. Motyka B, Reynolds JD. Apoptosis is associated with the extensive B cell death in the sheep ileal Peyer's patch and the chicken bursa of Fabricius: a possible role in B-cell selection. Eur J Immunol 1991; 21: 19511958.

29. Colotta F, Re F, Polentarutti N, Sozzani S, Mantovani A. Modulation of granulocyte survival and programmed cell death by cytokines and bacterial products. Blood 1992; 80: 2012-2020.

30. Bone RC, Fisher CJ, Clemmer TP, Slotman GJ, Metz CA, Balk RA, and the Methylprednisolone Severe Sepsis Study Group. A controlled clinical trial of high dose methylprednisolone in the treatment of sepsis and septic shock. N Engl J Med 1987; 317: 653-658.

31. Cox G. Glucocorticoid treatment inhibits apoptosis in human neutrophils: separation of survival and activation outcomes. J Immunol 1995; 154: 4719-4725.

32. Hiramatsu N, Hayashi N, Katayama K, et al. Immunohistochemical detection of Fas antigen in liver tissue of patients with chronic hepatitis C. Hepatology 1994; 19: 1354-1359.

33. Hagimoto N, Kuwano K, Nomoto Y, Kunitake R, Hara $\mathrm{N}$. Apoptosis and expression of Fas/Fas ligand mRNA in bleomycin-induced pulmonary fibrosis in mice. $\mathrm{Am}$ J Respir Cell Mol Biol 1996; 16: 91-101. 